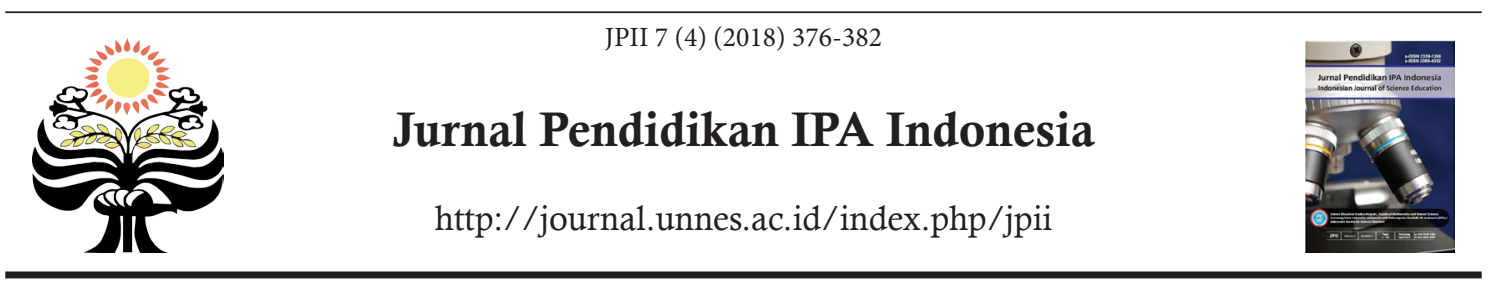

\title{
GEOMETRICAL OPTICS PROCESS IMAGE-BASED WORKSHEETS FOR ENHANCING STUDENTS' HIGHER-ORDER THINKING SKILLS AND SELF-REGULATED LEARNING
}

\author{
Sutarto $^{1}$, Indrawati*2, J. Prihatin ${ }^{3}$, P. A. Dwi ${ }^{4}$ \\ ${ }^{1}$ Physics Education Program, Faculty of Teacher Training and Education, Universitas Jember, Indonesia \\ ${ }^{2}$ Natural Science Education Program, Faculty of Teacher Training and Education, \\ Universitas Jember, Indonesia \\ ${ }^{3}$ Biology Education Program, Faculty of Teacher Training and Education, Universitas Jember, Indonesia \\ ${ }^{4}$ Department of Informatics Science, Graduate School of Science and Technology, Shizuka University
}

DOI: $10.15294 /$ jpii.v7i4.14563

Accepted: August 31 $1^{\text {st }}, 2018$. Approved: December 10 ${ }^{\text {th }}, 2018$. Published: December $29^{\text {th }}, 2018$

\begin{abstract}
This study intended to prove whether process image-based worksheets of geometrical optics could enhance students' higher-order thinking (HOTS) and self-regulated learning (SRL). This was quasi-experimental research of non-equivalent control group design. This research was conducted to grade 8 junior high school students at a junior high school in Jember district studying the geometrical optic. The sample was 70 students; 35 students belonged to an experimental group and the other 35 students in a control group. The HOTS data were obtained from test results and the SRL data were collected from questionnaire results. To determine the effect of using the worksheets on the students' HOTS and SRL, carried out was an independent t-test at a significance level of (2-tailed) $\alpha=0.05$. The results showed that the worksheets had a significant effect on the HOTS seen from $\alpha<0.05$ and that the $t_{\text {count }}>t_{\text {table }}$ at $\mathrm{df}=68$. In addition, the worksheets also owned a significant effect on the students' SRL seen from $\alpha<0,05$ and that the $t_{\text {count }}=14,692\left(>t_{\text {table }}\right)$. Thus, it concluded that the learning with the worksheets had a significant influence on the junior high school students' HOTS and SRL which are required for preparing their life in the 21 st century.
\end{abstract}

(C) 2018 Science Education Study Program FMIPA UNNES Semarang

Keywords: worksheets, process image, geometrical optics, HOTS, SRL

\section{INTRODUCTION}

Physics is a part of science that taught on senior high school students. Geometrical optics is a part of physics which can be learned through any learning printed media such as student worksheets. The development of science and technology in the 21st-century requires humans to be able to think in higher level or have higher order thinking skills (HOTS) and self-regulated learning (SRL) in overcoming problems in the world and

*Correspondence Address

E-mail: indrawatisutarto.fkip@unej.ac.id the everyday life due to the massive challenges that must be faced. The problem is: how to create student worksheets (SW) which can enhance students' HOTS and SRL?

The 21st-century science subject demands the development of students' HOTS since there is a significant relationship between HOTS and students' academic achievement (Ramos et al., 2013; Fariyani et al., 2017; Tanujaya et al., 2017; Gallagher et al., 2012). However, the needs analysis of learning HOTS for generating ideas is more difficult ( Heong et al., 2012). Other than that, students are also expected to be independent in 
learning or so-called the self-regulated learning (SRL) as it would affect their learning outcomes (Cheng, 2011; Law et al., 2008; Alibakhshi \& Zare, 2010). Daniela (2015) said that SRL should be involved in learning to enhance academic performance for the secondary school students. Hence, schools should facilitate every learning process of all subjects, especially science, for students to develop their HOTS and SRL.

Science is one of the junior high school subjects covering physics, chemistry, biology, astronomy, and geology; while the essence of science subject is a process, product, and attitude (Sutarto \& Indrawati, 2017; Trowbridge \& Bybee, 1990). The product of science subject includes facts, concepts, principles, theories, or laws. Meanwhile, the process refers to the way of obtaining the science products which covers ways, methods, or steps taken when solving a problem or finding the product knowledge. Such a process is called a scientific method which consists of seven stages: (1) defining the problem; (2) collecting information; (3) forming a hypothesis; (4) conducting an experiment; (5) recording observation and analyzing the data; (6) drawing up a conclusion; and (7) publishing the results (Passmore et al., 2009). Referring to the same sources, attitude defines as an individual response while conducting the stages of scientific methods such as honesty, objectivity, conscientious, perseverance, and curiosity. In sum, solving a science problem requires several steps done in an experiment.

As mentioned above, science fundamentally comprises process-product. Thus, good science learning does not only discuss product knowledge but also study the process of product making. Schools of a developing country like Indonesia generally do not implement the practice of science process, arguing that there are not sufficient facilities and too much time-consuming.

The practice of science process is needed in learning since it clarifies the logic mistakes of students towards a scientific phenomenon. For instance, provided were two colors (red and blue) mixed into purple (violet), but when asked about the results of mixing the primary colors (red, orange, yellow, green, blue, indigo, and purple), they answered incorrectly. Instead, their answer was black, or even a new color. Furthermore, they marveled that mixing all the colors results in white. This phenomenon indicates that the practice of science process is required in science learning.

The paradigm-shifting of school learning from knowledge transferring into learning transferring has elucidated that not all science topics taught in schools must be equipped with the practice of scientific process. Instead, the practice of science process intends to stimulate students' motor skills in science, and not to examine all science materials. The practice of science process ultimately aims at giving experience to students in examining a science phenomenon empirically, which would enrich their cognitive process in the form of intellectual skills (Conklin, 2005).

Science is a subject discussing either real or abstract events. The real science event is relatively easy to explain, while the abstract ones are quite complicated (Sutarto \& Indrawati, 2017). This means that although science learning has been equipped with sufficient learning sources and supported by the practice of the science process, teachers' explanation remains to be needed to teach the abstract concept. However, a learning process involving many teachers' explanation categorized as the knowledge transfer.

In accordance with the communication theory proposed by Severin \& Tankard (2001), a new oral/written information is initially accepted by an individual's sense before getting in the memory function stored as the new knowledge and deciphered into codes and pictures. This information coding is strongly influenced by knowledge, experience, codes, or pictures owned by the individual. Next, the new coded information would be stored as the individual's new knowledge. This theory gives an understanding that inaccuracy between the purpose and the individual's comprehension of the information is called misconception, which caused by the individual's inaccuracy in decoding the content. Therefore, helping students depict oral and written information before it is accepted as new information would minimalize the occurrence of misconception.

Objects learned in science are generally related to natural phenomena. Basically, learning natural phenomena is a process of observing the occurrence of a certain phenomenon. The length and abstractness of a phenomenon make it difficult to be understood by students. Thus, proper learning media is necessary for the sake of the students in learning abstract science concepts. Stefanikova \& Prokop (2015) explained that using the visual media by pictures could bridge the difficulties of abstract science concept and stimulate students' thinking process. Moreover, pictures as one of the visual media could assist learners in understanding a concept correctly and chronologically (Shabiralyani et al., 2015).

A process image is an image containing the processes or stages of changing the occurring phenomenon. Sutarto \& Indrawati (2017) interpreted the process image as a series of the object 
image (objects, events, or phenomena). The series of images always have a relative difference between one and another in terms of circumstances, position, form, or combination, which wholly depicts a coherent stage. If process images are used to embed a concept, it needs analysis and evaluation skills; in other words, HOTS. Thus, it is possible to learn science concepts by analyzing the steps or the transformation in the process image to make it easier for students to understand the concepts. In its presentation for learning, process images can be manifested through printed media such as student worksheets (SW).

Some studies on learning with process image-based printed media have been previously carried out. Sutarto \& Indrawati (2017) have shown that learning with process image-based printed media was effective for the collision concepts taught in senior high schools on the students' picture and graph representation skills as well as learning outcome improvement. Figure 1 is the process image example of collision concepts.

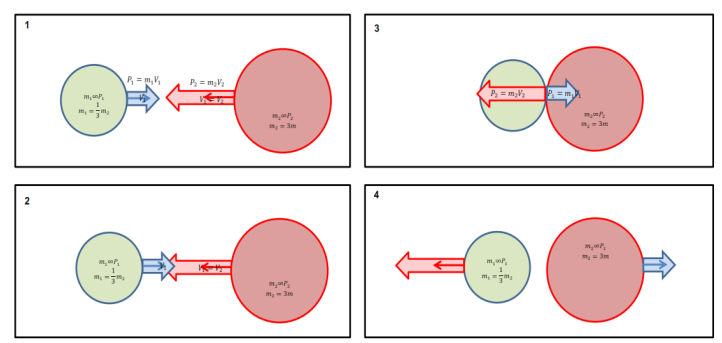

(Sutarto \& Indrawati, 2017)

Figure 1. The Collision Process Between Two Objects

The same research was carried out by Zainuri et al. (2017) showing that process image-based worksheets made students active, also, enhanced their learning outcomes and independence. The use of the process image is also effective for learning electrolyte and non-electrolyte solutions of students in high schools (Doymus et al., 2010).

Science subject in junior high schools mostly contains physics, biology, and geology. Geometrical optics is one of the subjects included in the syllabus of junior and senior high school science subjects. Geometrical optics is studied in physics talking about the behavior of light through a ray approach by applying geometrical principles. The rays in the geometrical optics are symbolized by a straight line whose direction of propagation follows the direction of light propagation. The concepts studied in geometric optics are the concepts of propagation, reflection, and refraction.

Interview results with several physics teachers stated that geometrical optics is a relatively simple physics topic. Nevertheless, this opinion turned out to be completely incorrect. Geometrical optics is not easily understood by the students, physic students or even physics teachers (Blizak et al., 2009; Kaltakci \& Eryilmaz, 2010; Vitharana, 2015; Kaltakci et al., 2016). The same thing is also shown by the results of the study conducted by Fariyani et al. (2017). The description illustrates the need for media that can help to facilitate students in understanding the concepts of geometrical optics and preventing conceptual errors.

Based on the interview results with several science teachers and observations on the implementation of geometrical optics learning in several regional schools in East Java, it obtained that almost all explanations of geometrical optics materials did not equip with a complete explanation of the process, such as the origin of normal line during the reflection and refraction, lack of complete marking of the beam sequencing at the geometrical optics process, and so on. Therefore, appropriate learning media should be provided to elucidate the process of the beam in forming the object shadows.

As previously explained, the process image-based worksheets are able to guide students to think about the way of analyzing the event process, for example, the way the light falls in the field of reflection (mirror) and the light sequence when falling in the field of refraction; also, interpreting the normal line, the angle of arrival, the bounce angle, and the bias angle. This allows students to more easily capture the provided information. The use of process images requires HOTS especially in analyzing and evaluating. Hence, it is said that the HOTS could be developed through images. The reason why the process image is manifested into printed form was to boost the students' independence learning. Therefore, a proof was needed whether the image process-based worksheets could affect the students' HOTS and instill their SRL.

\section{METHODS}

This research aimed at studying the impacts of using the geometrical optics process image-based worksheets on junior high school students to improve their HOTS and SRL. Hence, this was a quasi-experimental research of Static Group Comparison Design or known as NonEquivalent Control Group design (Fraenkel \& Wallen, 2009). The independent variable of this 
research was geometrical optics process imagebased worksheets while the dependent variable was the higher-order thinking skills (HOTS) and self-regulated learning (SRL). Based on the design, the students in both the experimental class (E) and control class (C) were tested their HOTS and SRL. The research subject was eight graders at one of the junior high schools in Jember Regency.

The instrument for measuring HOTS was two sets of test referring to the 4 th (analysis) and 5 th (evaluation) level of the revised Bloom's taxonomy (Conklin, 2005). There were 12 argumentative multiple questions each. The first set comprised reflection concepts (four questions of the reflection on a flat mirror, four questions of reflection on a concave mirror, and four questions of the reflection on a convex mirror) and the other set covered refraction concepts (four questions of the refraction on a flat mirror, four questions of the refraction on a concave mirror, and four questions of the refraction on a convex mirror). Of the 24 questions, it obtained 22 valid (logical validation results) and reliable items. The KR-20 reliability coefficient obtained 0.784 (good criteria); so, the reliability was acceptable (Dunn, et al, 2013).

The instrument used to measure SRL was a questionnaire adapted from (Ismail, et al., 2012) which has been declared valid at $\alpha=0.05$ with a corrected item-total correlation average of $0.79\left(\mathrm{r}_{\text {count }}>\mathrm{r}_{\text {table }}\right)$. Fraenkel \& Wallen (2009) stated that the minimum requirement of eligibility is $r=0.3$ and the instrument is said to be reliable if the Cronbach alpha value is $>0.6$ at $\alpha$ $=0.05$. Based on the results of the SRL questionnaire instrument trial, the value of Cronbach alpha was $0.986>0.6$ which categorized as very high of the value range (0.81-1.00). The developed SRL questionnaires consisted of 40 items containing 11 indicators, namely: (1) seeking information; (2) self-esteem; (3) environmental control; (4) peer learning; (5) self-evaluation; (6) strategy training; (7) controlling environmental motivation, (8) self-talk about learning efficiency, (9) self-talk about learning achievement, (10) time management, and (11) elaboration (Ismail\& Sharma, 2012). The SRL data were analyzed using a Likert scale of 1 to 5 . The criteria of SRL were very high $(\mathrm{VH})$, high $(\mathrm{H})$, intermediate $(\mathrm{I})$, low (L), and very low (VL), if the score between 80.1 - 100; 60,1 - 80; 40,1- 60; 20,1 - 40; and $0-20$ respectively.

To see the effect of the treatment on HOTS and SRL, the data analysis technique used was inferential statistics namely t-test or difference test to compare the students' HOTS and SRL in the experimental and control class. Before performing the t-test, the data must be tested for its normality and homogeneity to determine which type of test should be performed, either parametric or non-parametric. The t-test analysis employed the polled variance formula. Such formula is used when the number of samples is the same ( $\mathrm{n} 1=$ n2) and homogeneous. To calculate the t-test, the SPSS version 20 for Windows was employed.

\section{RESULTS AND DISCUSSION}

This research was carried out to eight graders of junior high school at Jember Regency; one class as the experimental class and the other as the control class consisting of 35 students each. The impacts of process image-based worksheets on the students' HOTS and SRL are explained as follows;

\section{The Impacts of Process Image-Based Worksheets on HOTS}

The impacts of using the geometrical optics process image-based worksheets for the reflection and refraction concepts on the students' HOTS, especially in the category of descriptive analysis and evaluation in both the experimental control class are presented in Table 1. This study determined two thinking skills because conceptual analyses of process image cannot help students to learn until they reach the creating level.

Table 1. The Descriptive Analysis Results of Students' Hots in the Experimental and Control Class

\begin{tabular}{ccccccccc}
\hline & \multicolumn{3}{c}{ Reflection Concept } & \multicolumn{3}{c}{ Refraction Concept } \\
\cline { 2 - 10 } HOTS elements & $\mathbf{E}(\mathbf{N}=\mathbf{3 5})$ & \multicolumn{2}{c}{$\mathbf{C}(\mathbf{N}=\mathbf{3 5})$} & $\mathbf{E}(\mathbf{N}=\mathbf{3 5 )}$ & \multicolumn{2}{c}{$\mathbf{C}(\mathbf{N}=\mathbf{3 5 )}$} \\
\cline { 2 - 10 } & $\mathbf{M}$ & $\mathbf{S D}$ & $\mathbf{M}$ & $\mathbf{S D}$ & $\mathbf{M}$ & $\mathbf{S D}$ & $\mathbf{M}$ & $\mathbf{S D}$ \\
\hline Analysis & 80.1 & 2.6 & 70.6 & 4.4 & 80.48 & 1.9 & 70.0 & 4.4 \\
Evaluation & 80.6 & 2.1 & 70.0 & 4.2 & 81.51 & 1.9 & 69.4 & 4.6 \\
\hline
\end{tabular}


Table 1 shows that the students' HOTS averages on the concept of reflection and refraction taught using the process image-based worksheets were almost the same; between $80-81$ in the experimental class and 69-71 in the control class with the same standard deviation. The difference between experiment and control class is caused by students' control class have several misconceptions of incident and reflection angle, and normal line. There are several students of control class that have difficulties for drawing of image formation process on a spherical lens. Figure 2 shows one form of students' misconception of image formation on a convex lens. Several students said that image is always located in front of an object and the distance object to lens equals image to a lens (red arrows).

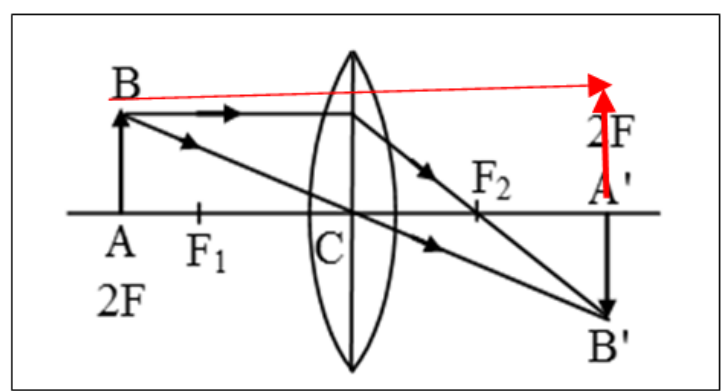

Figure 2. The Formation of a Spherical Lens (Convex Lens)

The analysis results of the independent sample t-test for the students' HOTS in the experimental and control class are explained as below.

The proposed hypotheses in this research were: (1) Ho: There was no difference between the average scores of the students' HOTS in the experimental (E) and control (C) class; and (2) Ha: The difference existed between the average scores of the students' HOTS in the experimental and control class. The basis of decision making: If the value was significant or sig. (2-tailed) $>0.05$ then Ho was accepted and $\mathrm{Ha}$ was rejected; or, if the value was significant or sig. (2-tailed) $<0.05$ then Ho was rejected and Ha was accepted.

Based on the SPSS analyses of the t-test, it indicated that the sig value. (2-tailed) of the HOTS on reflection and refraction topic, both at the analysis and evaluation aspects was all $<0.05$. This shows that Ho was rejected or Ha was accepted, meaning that the difference existed between the students' HOTS in the experimental class and the control class. As seen in Table 2, the average HOTS on the reflection and refraction materials for the experimental class was higher. This indicated that the use of process image-based worksheets for geometrical optics had an effect on the students' HOTS. This was consistent with the findings of Sutarto \& Indrawati (2017) revealing that the process image-based worksheets were effective for teaching the mechanics topic taught to high school students. The process image is a kind of visual media. Ainsworth et al. (2011) said that scientist making visualizations is integral to scientific thinking. Scientists do not use words only but rely on diagrams, graphs, videos, photographs, and other images to make discoveries, explain findings, and excite public interest. Raiyn (2016) showed that visual learning tools could increase the students' HOTS. Zainuri et al. (2017) also found that there was an effect of the process image-based worksheets for learning the light concept for junior high school students. Next, (Doymus et al., 2010) also found that printed media with process images was effective for learning the electrolyte and non-electrolyte solution materials in high schools. In addition, a clear task for analyzing process images was also influential to generate ideas in students, so that their higherorder thinking skills (HOTS) were developed primarily for analyzing and evaluating skills. This is in line with the results of the study conducted by (Davar, 2012) and Maries \& Singh (2017) concluded that productive diagram or process image also improved student's problem-solving. Heong et al. (2013) which stated that generating ideas are highly essential for emerging HOTS.

\section{The Impacts of Process Image-Based Worksheets on $S R L$}

Table 2 presents the impacts of the learning with process image-based worksheets for geometrical optics on the students' SRL seen from the average scores of the 11 indicators.

Table 2. The Comparison of Students' SRL in the Experimental and Control Class

\begin{tabular}{lllll}
\hline No & $\begin{array}{r}\text { Score } \\
\text { Range }\end{array}$ & Criteria & E & C \\
\hline 1 & $80,1-100$ & VH & 5 & 0 \\
2 & $60,1-80$ & H & 23 & 0 \\
3 & $40,1-60$ & I & 7 & 8 \\
4 & $20,1-40$ & L & 0 & 27 \\
5 & $0-20$ & VL & 0 & 0 \\
\hline
\end{tabular}

Table 2 indicates that the experimental class students had better SRL than the control class students. It informs that the highest, the average, and the lowest SRL score categorized as very high, high, and intermediate, while the control class classified as intermediate, low, and low. 
When looking at the score data analyses of SRL, the highest score of experiment class was 90, the lowest score was 45 , and the average score was 72.4. The control class' scores of SRL were 52,5 (highest score), 25 (the lowest score), and 38 (average score).

The significant influence of geometrical optics learning with the image process-based worksheets on the students' SRL was examined by the t-test analysis results as described below.

The proposed hypotheses in this research were: (1) Ho: There was no difference between the average scores of the students' SRL in the experimental and control class; and (2) Ha: The difference existed between the average scores of the students' SRL in the experimental and control class. The basis of decision making was; If the value was significant or sig. (2-tailed) $>0.05$ then Ho was accepted and Ha was rejected. If the value was significant or sig. (2-tailed) $<0.05$ then Ho was rejected and $\mathrm{Ha}$ was accepted.

Based on the data analysis results, the value of the sig. (2-tailed) for the SRL was $<0.05$, at $\mathrm{df}=68(\mathrm{t}$-table $=2,000$ at $\alpha=0,05)$, and the score of t-count $=14,692>$ t-table was obtained. Thus, the Ho was rejected or there was a difference between the students' SRL in the experimental and control class. If seen from the SRL average and SRL criteria in Table 2, the experimental class students' SRL was better. Hence, it concluded that the learning of geometrical optics with the process image-based worksheets could embed the SRL of experimental class students well. This was in line with the research results of (Zainuri et al., 2017) which revealed that learning with process image-based worksheets could improve students' self-regulated learning. In addition, when students utilize the process image-based worksheets, they automatically have the freedom to learn, such as seeking information, controlling the environment, being efficient in learning, and being able to repeat it (Ismail \& Sharma, 2012).

\section{CONCLUSION}

Based on the results and discussion, we could conclude that the geometrical optics process image-based worksheets could significantly influence the students' higher-order thinking skills, especially in the aspects of analyzing and evaluating for both reflection and refraction concepts. Besides that, the geometrical optics learning with the help of process image-based worksheets has proven to have a significant effect on the students' learning independence, meaning that the worksheets could instill the students' selfregulated learning.

Furthermore, the researchers suggested that teachers or printed media developers design many more proper process images to stimulate students in analyzing and finding out concepts (HOTS) through their independence of learning (SRL).

\section{REFERENCES}

Ainsworth, S., Prain, V., \& Tytler, R. (2011). Drawing to Learn in Science. Science, 333(6046), 10961097.

Alibakhshi, S. Z., \& Zare, H. (2010). Effect of Teaching Self-Regulated Learning and Study Skills on the Academic Achievement of University Students. Journal of Applied Psychology, 4(3), 6980.

Blizak, D., Chafiqi, F., \& Kendil, D. (2009, June). Students Misconceptions about Light in Algeria. In Education and Training in Optics and Photonics (p. EMA5). Optical Society of America.

Cheng, C. K. E. (2011). The Role of Self-Regulated Learning in Enhancing Learning Performance. The International Journal of Research and Review, 6(1), 28-38.

Conklin, J. (2005). A Taxonomy for Learning, Teaching, and Assessing: A Revision of Bloom's Taxonomy of Educational Objectives Complete Edition.

Daniela, P. (2015). The Relationship Between SelfRegulation, Motivation and Performance at Secondary School Students. Procedia-Social and Behavioral Sciences, 191, 2549-2553.

Doymus, K., Karacop, A., \& Simsek, U. (2010). Effects of Jigsaw and Animation Techniques on Students' Understanding of Concepts and Subjects in Electrochemistry. Educational Technology Research and Development, 58(6), 671-691.

Dunn, T. J., Baguley, T., \& Brunsden, V. (2014). From Alpha to Omega: A Practical Solution to the Pervasive Problem of Internal Consistency Estimation. British Journal of Psychology, 105(3), 399-412.

Fariyani, Q., Rusilowati, A., \& Sugianto, S. (2017). FourTier Diagnostic Test to Identify Misconceptions in Geometrical Optics. Unnes Science Education Journal, 6(3), 8-17.

Fraenkel, J. R., Wallen, N. E., \& Hyun, H. H. (2011). How to Design and Evaluate Research in Education. New York: McGraw-Hill Humanities/Social Sciences/Languages.

Gallagher, C., Hipkins, R., \& Zohar, A. (2012). Positioning Thinking within National Curriculum and Assessment Systems: Perspectives from Israel, New Zealand and Northern Ireland. Thinking Skills and Creativity, 7(2), 134-143.

Heong, Y. M. (2013). Contributing Factors towards Dif- 
ficulties in Generating Ideas Among Technical Students. Journal of Technical Education and Training, 5(1), 10-17.

Heong, Y. M., Yunos, J. M., Othman, W., Hassan, R., Kiong, T. T., \& Mohamad, M. M. (2012). The Needs Analysis of Learning Higher Order Thinking Skills for Generating Ideas. Procedia-Social and Behavioral Sciences, 59, 197-203.

Ismail, N. M., \& Sharma, A. (2012). Goal Orientation and Self-Regulated Learning Strategies as Predictors of EFL Students' GPA. Journal of Education Review, 5(1), 111-125.

Kaltakci, D., \& Eryilmaz, A. (2010). Sources of Optics Misconceptions. Contemporary Science Education Research: Learning and Assessment, 13-16.

Kaltakci-Gurel, D., Eryilmaz, A., \& McDermott, L. C. (2016). Identifying Pre-Service Physics Teachers' Misconceptions and Conceptual Difficulties about Geometrical Optics. European Journal of Physics, 37(4), 045705-045717

Law, Y. K., Chan, C. K., \& Sachs, J. (2008). Beliefs about Learning, Self-Regulated Strategies and Text Comprehension Among Chinese Children. British Journal of Educational Psychology, 78(1), 51-73.

Maries, A., \& Singh, C. (2017). Do Students Benefit from Drawing Productive Diagrams Themselves while Solving Introductory Physics Problems? The Case of Two Electrostatics Problems. European Journal of Physics, 39(1), 015703-015718.

Passmore, C., Stewart, J., \& Cartier, J. (2009). ModelBased Inquiry and School Science: Creating Connections. School Science and Mathematics, 109(7), 394-402.

Raiyn, J. (2016). The Role of Visual Learning in Improving Students' High-Order Thinking Skills. Journal of Education and Practice, 7(24), 115-121.

Ramos, J. L. S., Dolipas, B. B., \& Villamor, B. B. (2013). Higher Order Thinking Skills and Academic Performance in Physics of College Students:
A Regression Analysis. International Journal of Innovative Interdisciplinary Research, 4(1), 48-60.

Severin, W. J., \& Tankard, J. W. (2001). Communication Theories: Origins, Methods, and Uses in the Mass Media. Pearson College Division.

Shabiralyani, G., Hasan, K. S., Hamad, N., \& Iqbal, N. (2015). Impact of Visual Aids in Enhancing the Learning Process Case Research: District Dera Ghazi Khan. Journal of Education and Practice, 6(19), 226-233.

Štefaniková, S., \& Prokop, P. (2015). Do We Believe Pictures More or Spoken Words? How Specific Information Affects How Students Learn about Animals. Eurasia Journal of Mathematics, Science \& Technology Education, 11(4), 725-733.

Sutarto \& Indrawati. (2017). Penggunaan Lembar Kerja Siswa (LKS) Berbasis Gambar Proses (GP) untuk Pembelajaran Mekanika di SMA. Prosiding Seminar Pendidikan IPA VIII 2017. Surabaya: UNESA

Tanujaya, B., Mumu, J., \& Margono, G. (2017). The Relationship between Higher Order Thinking Skills and Academic Performance of Student in Mathematics Instruction. International Education Studies, 10(11), 78-85.

Trowbridge, L. W. \& Bybee, R. W. (1990). Becoming a Secondary School Science Teacher (5th ed). Colombus: Merril Publishing Company.

Vitharana, P. R. K. A. (2015). Students' Understanding of Light Concepts in the Secondary School. International Journal for Innovation Education and Research, 3(6), 7-14.

Zainuri, M., Sutarto, S., Supeno, S., Indrawati, I., \& Prihatin, J. (2017). Student Worksheet Science Based on Process Image of Light Concept for Learning in Junior High Schools. Pancaran Pendidikan, 6(4), 8-19. 